\title{
EWOLUCJA WYBRANYCH REGULACJI RYNKU PRACY - ANALIZA PORÓWNAWCZA ROZWIĄZAŃ AMERYKAŃSKICH NA TLE ROZWIĄZAŃ EUROPEJSKICH
}

\begin{abstract}
W opracowaniu omówiono kierunki zmian w procesie legislacyjnym określającym stosunki pracy w danej gospodarce. W odniesieniu do instytucji rynku pracy skupiono się przede wszystkim na poziomie ochrony zatrudnienia oraz na roli związków zawodowych. Analizę przeprowadzono w stosunku do następujących krajów: Stanów Zjednoczonych Ameryki Północnej oraz reprezentantów Unii Europejskiej - Niemiec, Wielkiej Brytanii, Francji i Włoch.

Przyjętą hipotezą badawczą jest twierdzenie, że regulacje rynku pracy w Stanach Zjednoczonych mają mniej restrykcyjny charakter niż w wybranych krajach Unii Europejskiej, co wpływa na uelastycznienie tego rynku pracy i jego szybsze dostosowania (mierzone stopa bezrobocia). Do weryfikacji tej hipotezy posłużyła metoda polegająca na analizie podstawowych zmian $w$ regulacjach rynku pracy wybranych przedstawicieli Unii Europejskiej oraz Stanów Zjednoczonych. Celem artykułu jest zatem prześledzenie kierunków zmian w procesie legislacyjnym prawa pracy i skonfrontowanie ich ze sobą w celu zweryfikowania postawionej hipotezy badawczej.

Praca składa się z pięciu części. W pierwszej z nich mowa jest o liberalnym charakterze regulacji rynku pracy w Stanach Zjednoczonych - analiza ta stanowi tło do porównań z krajami europejskimi. Część druga opracowania traktuje o negocjacjach i zasadzie współdecydowania jako podstawowych cechach stosunków pracy w Niemczech. W kolejnym punkcie skupiono się na zmianach legislacyjnych usztywniających rynek pracy $w$ ostatnich dwóch dekadach $\mathrm{w}$ Wielkiej Brytanii. Część czwarta omawia wspólny kierunek ewolucji prawa pracy w Unii Europejskiej i we Francji. Następnie w kolejnym punkcie mowa jest o współczesnych próbach uelastycznienia włoskiego rynku pracy zmianami legislacyjnymi. Pracę zamyka próba skonfrontowania amerykańskiego modelu z modelem europejskim.

Slowa kluczowe: rynek pracy, prawo pracy, Stany Zjednoczone, Europa
\end{abstract}

\section{WPROWADZENIE}

Efektywność rynku pracy w znacznej mierze zależy od instytucjonalnych ram narzuconych przez przepisy prawne danej gospodarki. Przyjmuje się, że zwykle nie ma znaczenia liczba wprowadzonych regulacji, lecz ich jakość oraz zgodność z instytucjami nieformalnymi, ukształtowanymi przez zwyczaje, kulturę czy mentalność społeczeństwa (tzw. odpowiedniość instytucji formalnych i nieformalnych).

W niniejszym opracowaniu mowa jest o kierunkach zmian w procesie legislacyjnym, który określa stosunki pracy $\mathrm{w}$ danej gospodarki. Skupiono się przede wszystkim na poziomie ochrony zatrudnienia oraz roli związków zawodowych. Taką analizę

\footnotetext{
${ }^{1}$ Dr Dorota Kuder, Katedra Teorii Ekonomii, Uniwerstet Ekonomiczny w Krakowie, ul. Rakowicka
} 27, 31-510 Kraków, e-mail: dorota.kuder@uek.krakow.pl 
przeprowadzono w stosunku do gospodarki Stanów Zjednoczonych Ameryki Północnej oraz w stosunku do czterech wybranych gospodarek krajów Unii Europejskiej (Niemiec, Wielkiej Brytanii, Francji i Włoch) ${ }^{2}$.

Celem opracowania jest zatem porównanie rozwiązań regulacyjnych stosowanych $\mathrm{w}$ Stanach Zjednoczonych w stosunku do analogicznych rozwiązań przyjętych na europejskich rynkach pracy. W związku z tak wyznaczonym celem badawczym przyjętą hipotezą badawczą jest twierdzenie: regulacje rynku pracy w Stanach Zjednoczonych mają mniej restrykcyjny charakter niż w krajach Unii Europejskiej, co wpływa na uelastycznienie tego rynku pracy i jego szybsze dostosowania (mierzone stopą bezrobocia).

Jako metodę badawczą przyjęto analizę podstawowych regulacji rynku pracy Stanów Zjednoczonych oraz wybranych przedstawicieli Unii Europejskiej. Prześledzenie kierunków zmian w procesie legislacyjnym prawa pracy i skonfrontowanie ich ze sobą pozwoliło na zweryfikowanie hipotezy badawczej.

\section{LIBERALNY CHARAKTER REGULACJI RYNKU PRACY W STANACH ZJEDNOCZONYCH}

Federalne prawo pracy w Stanach Zjednoczonych wydaje się obszerne i kompleksowe. Opiera się ono głównie na kilku ważnychaktach prawnych ${ }^{3}$ :

- Ustawie o zabezpieczeniu społecznym (The Social Security Act) z 1935 r. oraz Federalnej ustawie o podatku na wypadek bezrobocia (Federal Unemployment Tax Act) z 1939 r. regulujących problem bezrobocia i podatków dotyczących zabezpieczenia społecznego;

- Narodowej ustawie o stosunkach pracy (The National Labor Relations Act) z 1935 r. ${ }^{4}$ zawierającej kluczowe przepisy dotyczące związków zawodowych i działań zbiorowych;

- Ustawie o uczciwych warunkach pracy (The Fair Labor Standards Act) z 1938 r. $^{5}$, która reguluje kwestie związane z płacami minimalnymi, wynagrodzeniami za nadgodziny, pracę dzieci, problem dyskryminacji (equal pay for equal work);

\footnotetext{
${ }^{2}$ Gdyby mierzyć rynek pracy liczbą zatrudnionych, to spośród 27 krajów należących do Unii Europejskiej największym rynkiem pracy w 2008 r. dysponowały Niemcy $(38,9 \mathrm{mln})$, Wielka Brytania $(29,4 \mathrm{mln})$, Francja $(25,9 \mathrm{mln})$ i Włochy $(23,4 \mathrm{mln})$ - dane OECD zaczerpnięte z http://stats.oecd.org/. Te kraje jako reprezentacja Unii Europejskiej wybrano do analizy w niniejszym opracowaniu. Uzasadnieniem takiego wyboru jest przede wszystkim to, że w $2008 \mathrm{r}$. łączna liczba zatrudnionych w tych krajach stanowiła 58,4\% wszystkich zatrudnionych na terenie UE (łączne zatrudnienie we wszystkich krajach UE w 2008 r. wyniosło 221673 tys. osób). Analogiczny wskaźnik odnoszący się do odsetka osób stanowiących zasoby siły roboczej czterech wybranych krajów UE w stosunku do wszystkich krajów Unii Europejskiej w 2008 r. był nieco niższy - wyniósł 53,2\%. Ten wynik może być jednak kolejnym argumentem za wyborem wskazanych krajów jako reprezentacji UE. Zatem regulacje rynku pracy Niemiec, Wielkiej Brytanii, Francji i Włoch versus regulacje rynku pracy Stanów Zjednoczonych staną się przedmiotem analizy tej pracy.

${ }^{3}$ The Economist Intelligence Unit, US Regulation - Human Resouces: Labour Law, Country Commerce United States, September 1996 oraz The Economist Intelligence Unit, US RegulationHuman Resouces: Labour Law, Country Commerce United States 2012.

${ }^{4}$ Zob. więcej: http://www.dol.gov/dol/topic/labor-relations/index.htm\#.UOlLOOSZQhw.

${ }^{5}$ Zob. więcej: http://www.dol.gov/compliance/laws/comp-flsa.htm\#.UOlKqeSZQhw.
} 
- Ustawie o bezpieczeństwie i higienie pracy (The Occupational Safety and Health Act) z 1970 r. ${ }^{6}$ określającej standardy warunków pracy;

- Ustawie o pracowniczym zabezpieczeniu emerytalnym (The Employee Retirement Income Security Act) z 1974 r. ${ }^{7}$ regulującej przepisy dotyczące tych pracodawców, którzy zobligowani są do zaoferowania swoim pracownikom planów emerytalnych i świadczeń opieki społecznej;

- Ustawie o wcześniejszym powiadomieniu pracowników o zwolnieniach grupowych (The Worker Adjustment and Retraining Notification Act) z 1988 r. ${ }^{8}$ narzucająca obowiązek na pracodawcę poinformowania pracowników o zwolnieniach grupowych z sześćdziesięciodniowym wyprzedzeniem;

- Ustawie o prawach obywatelskich (Civil Rights Act) z 1991 r. ${ }^{9}$, która określa równość szans w zatrudnianiu, wynagradzaniu i zwalnianiu pracowników;

- Ustawa o nieobecności w pracy $\mathrm{z}$ powodów rodzinnych lub medycznych (The Family and Medical Leave Act) z 1993 r. $^{10}$ normującej kwestie dotyczące przyczyn oraz okresu ochronnego dla pracownika nieobecnego w pracy.

$\mathrm{Na}$ szczególne uwzględnienie w analizie prawa pracy zasługuje stosowane w Stanach Zjednoczonych prawo dotyczące dyskryminacji w zakresie zatrudnienia (equalopportunity employment). Prawo to, nazywane także przepisami równości szans $\mathrm{w}$ zatrudnieniu, odnosi się zarówno do procesu zatrudnienia, zwalniania, jak i wynagradzania pracowników. Organem odpowiedzialnym za tę dziedzinę jest Federalna Komisja ds. Równych Szans Zatrudnienia.

Ogólnie rzecz ujmując, amerykańscy pracownicy są świadomi swoich praw i charakteryzują się wręcz upodobaniem do sądowego zaskarżania pracodawcy w wypadku spostrzeżenia jakiegokolwiek naruszenia przepisów. Ciekawejest to, że w takich przypadkach ciężar dowodu $w$ sprawach o dyskryminację spoczywa zwykle na pracodawcy, co oznacza, że zakłada się z góry, że doszło do dyskryminacji, do momentu przeciwnego dowodu ze strony pracodawcy (swoiste domniemanie winy). Do takiej praktyki przyczyniła się Ustawa o prawach obywatelskich z $1991 \mathrm{r}$. Jeżeli pracodawca prowadził praktyki, które miały wpływ na chronioną grupę pracowników, jedyne co mu pozostaje przy przyjęciu domniemania prowadzenia praktyk dyskryminacji, to udowodnienie, że jego działania były „zgodne z konieczną praktyką prowadzenia interesów" (consistent with business necessity) ${ }^{11}$.

Raport European Intelligence Unit uznaje Stany Zjednoczone za lidera w dziedzinie ochrony zdrowia i bezpieczeństwa pracowników ${ }^{12}$. Pogląd ten może wydawać się nieco kontrowersyjny, jeżeli przyjrzeć się bliżej amerykańskim statystykom wypadków przy

\footnotetext{
${ }^{6}$ Zob. więcej: http://www.dol.gov/compliance/laws/comp-osha.htm\#.UOIIuuSZQhw.

${ }^{7}$ Zob. więcej: http://www.dol.gov/dol/topic/retirement/erisa.htm\#.UOlJK-SZQhw.

${ }^{8}$ Zob. więcej: http://www.dol.gov/compliance/laws/comp-warn.htm\#.UOlJbeSZQhw.

${ }^{9}$ Zob. więcej: http://www.dol.gov/oasam/regs/statutes/Civil-Rights-Act-of-1991.doc.

${ }^{10}$ Zob. więcej: http://www.dol.gov/dol/topic/benefits-leave/fmla.htm\#.UOlKRuSZQhw.

${ }^{11}$ Termin ten nie ma jednak jednoznacznej interpretacji prawnej, co pozwala prawnikom na jego różnorodną interpretację, a przez to często na skuteczną obronę pracodawcy przed konsekwencjami prawnymi praktyk dyskryminacji.

${ }^{12}$ The Economist Intelligence Unit, US Regulation - Human Resouces: Labour Law, Country Commerce United States, September 1996.
} 
pracy $^{13}$. W tej dziedzinie, podobnie jak w wypadku ochrony środowiska, poszczególne stany mogą zdecydować się na przyjęcie surowszych przepisów niż te stosowane przez rząd federalny. Praktycznie wszystkie rodzaje przedsiębiorstw objęte są wdrożeniem stanowego i federalnego standardu higieny i bezpieczeństwa miejsca pracy, a zwyczajowo ciężar ochrony pracowników spoczywa na pracodawcy. Zakłady pracy przechodzą okresowe kontrole zgodności z przyjętym zestawem standardów, mogą one pociągać za sobą ujawnienie naruszenia prawa związane z narzuceniem kar i sankcji. Płacone przez pracodawców składki są podstawą wypłaty odszkodowań dla pracowników.

Narodowa „Ustawa o stosunkach pracy z 1935 r.” (tzw. ustawa Wagnera) jest podstawowym federalnym zbiorem regulacji stosunków pracy i ustalania praw związków zawodowych i ich członków. Nie doczekała się ona wielu zmian czy reform, stąd zarówno uzwiązkowienie, jak i świadomość klasowa w Stanach Zjednoczonych nigdy nie osiągnęły poziomów obserwowanych w większości krajów Europy Zachodniej. Amerykańskie prawo pracy oparte jest na założeniu kontradyktoryjności relacji klasy pracowników (robotników) z pionem zarządzającym. Istnieje zatem powszechnie domniemanie występowania antagonistycznych interesów obu klas, co ma krwawe historyczne podłoże. Tradycyjne formy ruchu związkowego bywały w przeszłości skutecznie thumione, czemu sprzyjała ostra konkurencja międzynarodowa i polityczne (a także legislacyjne ${ }^{14}$ ) ataki na próby organizowania się pracowników. W rezultacie współcześnie wiele firm eksperymentuje $\mathrm{z}$ nowymi modelami zarządzania, typu partnerskiego. Zainteresowanie $\mathrm{w}$ partycypacyjnych technikach zarządzania na wzór japoński jest coraz większe zarówno wśród pracowników szeregowych, jak i kadry kierowniczej wyższego szczebla.

Ustawa Wagnera z 1935 r. gwarantuje prawo do tworzenia związków i zakazuje pracodawcom związków dominujących (company union). Zobowiązuje też pracodawcę do prowadzenia rokowań $\mathrm{w}$ dobrej wierze. Jednakże akt ten uległ pewnym reformom związanym z wprowadzeniem poprawek przez Roberta Tafta i Freda A. Hartleya Jr. (Ustawa Tafta-Hartleya) z 1947 r. Poprawki te zmniejszyły zakres i skuteczność strajków, bojkotów i pikiet, a więc podstawowej broni pracowników. Dodatkowo zakazywał on wszelkich akcji solidarnościowych oraz akcji wtórnych (poza zakładem pracy). Uchylał on również tzw. klauzulę prawa do pracy (right-to-work) - paragraf 14(b) Ustawy Wagnera - i skutecznie zahamował wzrost uzwiązkowienia. Wspomniany paragraf 14(b)

\footnotetext{
${ }^{13}$ Liczba wypadków śmiertelnych w pracy oraz uszczerbku zdrowia świadczy o słabej ochronie pracownika. I chociaż spada liczba śmiertelnych wypadków przy pracy - do połowy lat osiemdziesiątych XX wieku roczna liczba takich wypadków wynosiła powyżej 13 tys. rocznie, a w ostatnich latach waha się w przedziale 4,7-5,1 tysięcy rocznie, to jednak liczba wypadków ze stratą zdrowia lub życia wzrosła z 2,2 miliona w latach siedemdziesiątych do 3,5-3,7 miliona rocznie w kilku ostatnich latach (dane U.S. Census Bureau 2010).

${ }^{14}$ Najbardziej znanym przykładem jest Ustawa Tafta-Hartleya z 1947 r. wprowadzona przez antylewicową administrację republikańską (wspieraną przez przedsiębiorców) jako poprawka do Narodowej ustawy o stosunkach pracy z 1935 r. Akt ten, mimo sprzeciwu Harry'ego Trumana (ówczesnego prezydenta Stanów Zjednoczonych), m.in. zabraniał komunistom zajmowania stanowisk związkowych. Niedługo później Sąd Najwyższy uchylił ten zapis, uznając go za niezgodny z Konstytucją Stanów Zjednoczonych, jednakże omawiana ustawa zainicjowała okres, trwający właściwie do dziś, ograniczania praw pracowniczych. Por. S.G. Kozłowski, Wpółczesna Ameryka. Mity i rzczywistość, Wydawnictwo Uniwersytetu Marii Curie-Skłodowskiej, Lublin 2001, s. 118.
} 
był zapisem, który wprowadzał zakaz dla pracowników i kierownictwa przedsiębiorstwa prowadzenia negocjacji bezpieczeństwa związkowego. W praktyce oznaczało to, że wszyscy pracownicy partycypujący w korzyściach $\mathrm{z}$ porozumień zbiorowych powinni partycypować również w kosztach tychże porozumień. Dodatkowo akt ten pozwalał pracodawcy na przeciwstawianie sobie różnych grup pracowniczych oraz zatrudnianie przeciwników związków, co w praktyce często oznaczało ich likwidację w miejscu pracy. Ustawa Tafta-Hartleya wprowadziła też regulacje zasad przygotowywania umów między pracodawcą a pracownikami - zakładała koncyliacyjny charakter obu stron w sporach dotyczących warunków pracy - w sytuacji braku porozumienia przewagę uzyskiwał pracodawca nad pracownikami. Kolejnym zapisem ustawy z 1947r. było uznanie za nielegalne tzw. closed shops, czyli umowy między związkiem zawodowym a pracodawcą, w której pojawił się zapis, że zakład pracy zatrudni tylko tych, którzy już należą do związku. I wreszcie w ustawie pojawił się zapis, że prezydent zyskuje prawo do ogłaszania cooling-off periods, czyli do ogłoszenia trzymiesięcznego okresu spokoju społecznego, gdy prezydent uzna, że dany spór narusza interes kraju. Celem było wyciszenie i złagodzenie konfliktu pracownik-pracodawca.

Proces tworzenia związku zawodowego w Stanach Zjednoczonych jest bardzo skomplikowany i długotrwały, a jego przejście nie gwarantuje powodzenia. Inicjuje go zebranie podpisanych kart autoryzacji związku zawodowego od co najmniej $30 \%$ pracowników danej grupy zawodowej, lecz ich zgromadzenie wiąże się z wieloma problemami.

Umowy między związkami a pracodawcami są zawierane na trzyletnie okresy i składają się z reguły z czterech części:

1) zasady bezpieczeństwa związku i prawa kierownictwa przedsiębiorstwa;

2) zasady pracy i płacy;

3) zasady indywidualnego bezpieczeństwa pracownika;

4) zasady egzekwowania umowy.

W 2008 r. do związków zawodowych przynależało około 16 milionów pracowników, wśród nich 7 milionów 832 tysiące byli pracownikami sektora publicznego, a pozostałe 8 milionów 265 tysięcy - pracownikami sektora prywatnego. Uzwiązkowienie w tym samym roku wyniosło ogółem 12,4\% zatrudnionych, odpowiednio 36,8\% dla sektora publicznego, a 7,6\% dla sektora prywatnego. Analizując te wskaźniki w czasie, szacuje się, że w Stanach Zjednoczonych w 1930 r. ok. 6-7\% zatrudnionych należało do związków zawodowych, w 1945 r. aż 35,5\%, w 1983 r. wynik obniżył się ${ }^{15}$ do 20,1\%, a w pierwszej dekadzie XXI wieku osiągnął poziom $12-13 \%{ }^{16}$.

Amerykańskie standardy warunków pracy zasadniczo opierają się na wykorzystaniu wysokich wynagrodzeń bezpośrednich zamiast świadczeń dodatkowych oraz na zbiorowych lub indywidualnych negocjacjach, a nie ustawodawstwie społecznym.

Wiek emerytalny dla pełnego korzystania z przywilejów zabezpieczenia społecznego (Social Security) lub programu Old Age Survivors Insurance (OASI) historycznie wynosił 65 lat, ostatnio jednak podniesiono go do 67. Ciekawostką może być fakt, że około $20 \%$

\footnotetext{
${ }^{15}$ Uzwiązkowienie znacznie spadło za czasów kadencji prezydentów republikańskich - Ronalda Reagana oraz George'a Busha.

${ }^{16}$ U.S. Census Bureau, Government Employment \& Payroll 2010, http://www.census.gov/govs/apes/.
} 
zatrudnionych Amerykanów znajduje się w przedziale wiekowym 6570 lat, ci zaś, którzy przekroczyli 70. rok życia, stanowią aż $5 \%$ zasobu pracujących. ${ }^{17}$

Stosunkowo „świeża” jak na ustawodawstwo amerykańskiego rynku pracy jest „Ustawa o nieobecności w pracy z powodów rodzinnych lub medycznych” (FMLA). Obowiązujące od 1993 r. prawo pozwala na wykorzystanie do 12 tygodni urlopu bezpłatnego w każdym 12-miesięcznym okresie z następujących powodów: narodzin dziecka pracownika i opieki nad nim, adopcji lub zastępczej opieki nad dzieckiem powierzonym pracownikowi, opieki nad najbliższym członkiem rodziny (małżonkiem, dzieckiem, rodzicem) zwzględu na jego poważny stan zdrowia lub ratowanie przez pracownika stanu własnego zdrowia, określonego jako poważny, ewentualnie jakikolwiek przymus związany z tym, że małżonek, dziecko lub rodzic pracownika jest w czynnej służbie wojskowej. Ustawa FMLA pozwala również małżonkowi, dziecku, rodzicowi lub krewnemu na skorzystanie z maksymalnie 26 tygodni urlopu na opiekę nad członkiem sił zbrojnych z powodu poważnej kontuzji lub choroby. Co ważne, FMLA odnosi się do wszystkich instytucji publicznych i prywatnych oraz przedsiębiorstw zatrudniających co najmniej 50 pracowników.

Rynek pracy w Stanach Zjednoczonych charakteryzuje się niskim poziomem ochrony zatrudnienia, wyjątek może stanowić jedynie ochrona przed dyskryminacją. Wynika to głównie $\mathrm{z}$ niskiego stopnia uzwiązkowienia oraz ze względów historycznych amerykański rynek pracy można określić mianem rynku pracodawcy. Wiele antyzwiązkowych uregulowań prawnych oraz niechęć mediów do związków zawodowych osłabiają tam pozycję związkowców.

\section{NEGOCJACJE I ZASADA WSPÓŁDECYDOWANIA JAKO PODSTAWOWE CECHY STOSUNKÓW PRACY W NIEMCZECH}

W gospodarce niemieckiej nie istnieje jednolite prawo regulujące indywidualne i zbiorowe aspekty zatrudnienia. Relacje między kadrą zarządzającą a pracownikami formowane są głównie podczas negocjacji zbiorowych między związkami zawodowymi i pracodawcami ${ }^{18}$. Umowa o pracę postrzegana jest jako szczególna forma umowy o świadczenie usług, regulowana zaś przez kodeks cywilny (te ogólne przepisy mają zastosowanie do wszystkich rodzajów stosunków pracy, a główne zastosowanie ma tutaj kodeks handlowy oraz art. 9 niemieckiej konstytucji).

W lipcu 1995 r. parlament uchwalił Ustawę korygującą o prawie pracy (Gesetz zur Anpassung arbeitsrechtlicher Bestimmungen $)^{19}$, która dostosowuje prawo niemieckie do wytycznych UE dotyczących porozumień płacowych. Akt ten zobowiązał pracodawców do formułowania na piśmie warunków umowy o pracę w ciągu jednego miesiąca od rozpoczęcia pracy (choć umowy pisemne od lat były standardem w gospodarce niemieckiej). Prawo niemieckie honoruje prawo zagraniczne w zakresie regulacji umowy o pracę, o ile okoliczności zatrudnienia są zasadniczo związane z prawem zagranicznym (generalnie obowiązującym prawem jest prawo państwa, w którym pracownik świadczy

\footnotetext{
${ }^{17}$ Dane OECD, Pensions at a Glance 2005, http://www.oecd.org/els/socialpoliciesanddata/pensionsataglance2005.htm.

${ }_{18}$ The Economist Intelligence Unit, Germany Regulation - Human Resouces: Labour Law, Country Commerce United States, May 2012.

${ }^{19}$ Zob. więcej: http://archiv.jura.uni-saarland.de/BGB1/TEIL1/1995/19950946.A10.HTML.
} 
pracę lub w którym mieści się zatrudniający pracownika oddział firmy, jeżeli pracownik pracuje za granicą - art. 30 II (EGBGB, Einführunggesetz zum Bürgerlichen Gesetzbuch).

Okres wypowiedzenia dla stosunku pracy został ujednolicony w 1993 r. na mocy Ustawy o okresie wypowiedzenia (Kündigungsfristengesetz, opublikowane w Gestetzblatt 14 października 1993) ${ }^{20}$. Zarówno pracowników niewykwalifikowanych (bezpośrednioprodukcyjnych), jak i wykwalifikowanych (pośrednioprodukcyjnych) obowiązuje miesięczny termin wypowiedzenia ${ }^{21}$ (związki zawodowe rygorystycznie przestrzegają tej zasady). Oczywiście istnieje możliwość zmiany proponowanego rozwiązania $\mathrm{w}$ zakresie wypowiedzenia stosunku pracy na zasadzie indywidualnych negocjacji.

W Niemczech zatrudnianie nieletnich poniżej 14. roku życia jest nielegalne. Pracodawcy muszą traktować pracowników obu płci jednakowo w odniesieniu do zatrudniania, zwalniania, warunków pracy i awansów. Godziny pracy są regulowane przez umowy związkowe. W październiku 1995 r. Przemysłowy Związek Zawodowy IG Metall przeforsował 35-godzinny tydzień pracy w przemyśle motoryzacyjnym i inżynierii. Mimo że była to historyczna zmiana dla pracowników, już o 1994 r. ponad 20\% niemieckich pracowników pracowało w takim wymiarze godzin ${ }^{22}$.

W czerwcu 1994 r. parlament uchwalił przełomowe prawo, które pozwala na większą elastyczność $\mathrm{w}$ podziale godzin pracy w ciągu tygodnia. Prawo o standaryzacji i zwiększeniu elastyczności przepisów o czasie pracy (Arbeitsgesetz zur Vereinheitlichung und Flexibiliarsierung des Arbeitszeitrecht ${ }^{23}$ pozwalało na wydłużone godziny pracy w wyjątkowych sytuacjach, takich jak czasowy wzrost zamówień. Takie wydłużenie czasu pracy musiało być uzgodnione z przedstawicielami pracowników i pozwalało na pracę do 60 godzin tygodniowo, $\mathrm{z}$ zastrzeżeniem maksymalnie dziesięciu godzin dziennie, $\mathrm{z}$ minimalną przerwą 11 godzin przed ponownym przystąpieniem do pracy.

W Niemczech pełnopłatny urlop chorobowy może trwać do sześciu tygodni. Minimalny roczny okres urlopu wynosi 24 dni roboczych dla pracowników zatrudnionych w pełnym wymiarze czasu pracy. Jednakże pracownicy są uprawnieni do corocznych urlopów w wymiarze średnio 30 dni na podstawie porozumienia związkowego.

Artykuł 9 niemieckiej konstytucji (Grundgesetz) ${ }^{24}$ gwarantuje swobodę pracownikom do zrzeszania się w celu poprawy zakładowych i ekonomicznych warunków pracy - czyli do zawierania układów zbiorowych (Tarifvertrage).

Współdecydowanie - czyli wspólny udział pracowników i kadry zarządzającej w decyzjach politycznych - jest historycznie cechą charakterystyczną przedsiębiorstw gospodarki niemieckiej (Niemiec Zachodnich). W przedsiębiorstwie zatrudniającym więcej niż pięciu pracownikówmogą oni utworzyć rady zakładowe (Betriebsrat), które pomagają rozwiązywać problemy kadrowe (np. godziny pracy, harmonogramy, wakacje, wynagrodzenia i struktury płac, wynagrodzenia pracy na akord i premie motywacyjne) oraz muszą być informowane o wszelkich zmianach, które dotyczą warunków pracy (np.

\footnotetext{
${ }^{20}$ http://archiv.jura.uni-saarland.de/BGB1/TEIL1/1993/19931668.1.HTML.

${ }^{21}$ Obowiązujące wcześniej prawo przewidywało dla pracowników wykwalifikowanych sześciotygodniowy termin wypowiedzenia, a dla niewykwalifikowanych - dwutygodniowy.

${ }^{22}$ The Economist Intelligence Unit, Germany Regulation - Human Resouces: Labour Law, Country Commerce Germany, September 1996.

${ }^{23}$ Zob. więcej: http://www.buzer.de/gesetz/6425/index.htm.

${ }^{24}$ Zob. więcej: http://dejure.org/gesetze/GG.
} 
zmiany w metodach produkcji i urządzeniach). Rada zakładowa ma także ważny głos w procesie zatrudniania, przeniesienia lub zwolnienia pracownika.

Prawo o współdecydowaniu (Betriebsverfassungsgesetz BGBl. I, 1972, S. 13 z 1972 r. ze zmianami z 2001 r. BGBl. I, S. 2518 oraz Mitbestimmungsgesetz BGBl. I, 1976, S. 1153 z 1976 r. $)^{25}$, określa zasady działania rad zakładowych i reprezentacji pracowniczej w zarządach. W przedsiębiorstwie zatrudniającym ponad 100 pracowników rada zakładowa może wybrać reprezentację, która omawia z kadrą zarządzającą decyzje administracyjne, a następnie przekazuje te informacje radzie zakładowej. W firmach o zatrudnieniu 5002000 pracowników jedna trzecia miejsc w radzie nadzorczej musi być zarezerwowana dla przedstawicieli pracowników. Te przedsiębiorstwa, które zatrudniają ponad 2000 pracowników, dla przedstawicieli pracowników zabezpieczają połowę miejsc w radzie nadzorczej (wymóg 50\% reprezentacji pracowników w radzie nadzorczej). Proces tworzenia polityki nadzorczej w każdym dużym przedsiębiorstwie musi opierać się na współpracy równej liczby (zazwyczaj dziesięciu) akcjonariuszy i przedstawicieli pracowników. W wypadku sporu decydujący głos znajduje się po stronie akcjonariuszy. Ponadto zasada współdecydowania w przedsiębiorstwach wielonarodowych zapisana jest w prawie unijnym. Dyrektywa w sprawie ustanowienia rad zakładowych $(94 / 45 / \mathrm{WE})$ nakłada obowiązek na pracodawcę konsultowania się z pracownikami i informowania ich o sytuacji firmy, jeżeli zatrudnia ona ponad 1000 pracowników w UE, z których co najmniej po 150 jest obywatelami dwóch państw członkowskich (wyłączając Wielką Brytanię). Państwa członkowskie rozpoczęły wdrażanie tej dyrektywy od 1996 r. (poza Wielką Brytanią i Danią), w Niemczech obowiązuje ona jednak od czerwca 2011 r. W 2012 r. funkcjonowało 320 europejskich rad pracowniczych w Niemczech ${ }^{26}$.

Od 2001 r. w przedsiębiorstwach zatrudniających co najmniej 15 pracowników możliwa jest praca $\mathrm{w}$ niepełnym wymiarze godzin. Jednak ustawa ta (Teilzeit- und Befristungsgesetz, BGBl. I, 2000, S. 1966) ${ }^{27}$ stosuje się do tych pracowników, którzy pracowali w firmie przez co najmniej sześć miesięcy.

Zmiany wprowadzane $\mathrm{w}$ ustawodawstwie niemieckiego rynku pracy mają bezsprzecznie na celu jego uelastycznienie. Ciekawym rozwiązaniem jest omówiona zasada współdecydowania pracowników o losach przedsiębiorstwa, co jest swoistym wyróżnikiem gospodarki Niemiec w stosunku do większości gospodarek na świecie.

\section{USZTYWNIENIE RYNKU PRACY W WIELKIEJ BRYTANII POPRZEZ ZMIANY LEGISLACYJNE OSTATNICH DWÓCH DEKAD}

Od 1979 r. do maja 1997 kolejne konserwatywne rządy zatwierdziły kilka reform dotyczących ustawodawstwa stosunków pracy, które osłabiły związki zawodowe oraz (w niektórych przypadkach) przyczyniły się do ochrony indywidualnych pracowników z arbitralnych działań ze związkami, co przyczyniło się do liberalizacji rynku pracy $\mathrm{w}$ Wielkiej Brytanii.

Pierwszy z aktów - Ustawa o zatrudnieniu z 1980 r. (Employment Act) ${ }^{28}$ - daje pracodawcom swobodę w decydowaniu, czy uznać związek za legalny w zakładzie pracy;

\footnotetext{
${ }^{25}$ Zob. więcej: http://www.buzer.de/gesetz/2034/index.htm.

${ }^{26}$ The Economist Intelligence Unit, Germany Regulation - Human Resouces: Labour Law, Country Commerce Germany, May 2012.

${ }^{27}$ Zob. więcej: http://dejure.org/gesetze/TzBfG.

${ }^{28}$ Zob. więcej: http://www.legislation.gov.uk/ukpga/1980/42.
} 
zakazuje pikiet w innym miejscu niż we własnym miejscu pracy pracownika oraz ogranicza, bez faktycznego zakazu, akcję pomocniczą związków. Z kolei Ustawa z 1982 r. $^{29}$ przyjęła zapisy o możliwości wejścia przez pracodawcę na drogę sądową przeciwko związkom zawodowym, co stanowiło uznanie w świetle prawa, że związki zawodowe są odpowiedzialne za działania swoich przedstawicieli. Dodatkowe zapisy dotyczyły zakazu strajków, które nie dotyczą sporów między pracownikami i ich pracodawcami związanych z zatrudnieniem, zakazu strajków związanych z przywilejami typu union shop ${ }^{30}$ lub closed $s h o p^{31}$ oraz rozszerzyły ochronę pracowników nad pracownikami, którym grozi utrata pracy z powodu braku członkostwa w związku.

Ustawa o związkach zawodowych z 1984 r. (Trade Union Act) ${ }^{32}$ dała prawo członkom związku decydowania $\mathrm{w}$ formie tajnego głosowania o wyborze kierownictwa związku, o środkach finansowych i o zwołaniu strajku (w tym przypadku głosowanie musi być nadzorowane).

Zmiany Ustawy o zatrudnieniu z $1988^{33}$ r. jeszcze mocniej zacieśniły kontrolę nad związkami, uniemożliwiając uznanie strajku za legalny w sytuacji, gdyby do takiej decyzji doszło bez tajnego głosowania; podobnie nieskuteczna była decyzja o wyborze liderów związków bez procedury tajnego głosowania. Dodatkowo członkowie związków zyskali prawo do kontroli finansów swoich związków. Akt ten ustanowił Rzecznika Praw Związkowych (Commissioner for the Rights of Trade Union Members), którego celem działania miała być nie tylko pomoc w postępowaniu członkom związków, ale i ochrona przed zwolnieniem za brak członkostwa w myśl Ustawy z $1982 \mathrm{r}$.

Ustawa o zatrudnieniu z $1990 \mathrm{r}^{34}$ zapewniła z kolei każdemu możliwość odwołania się lub zaskarżenia decyzji o odmowie pracy ze względu na przynależność związkową czy też z powodu jej braku. Poza tym akt ten zakazywał akcji mających na celu popieranie pracownika zwolnionego $\mathrm{z}$ powodu prowadzenia nieoficjalnego (nielegalnego) strajku oraz dawała pracodawcom większą swobodę w zwalnianiu pracowników biorących udział w nieoficjalnych działaniach szkodzących przedsiębiorstwu.

Reforma ustawodawstwa o związkach zawodowych i Ustawa o prawach pracowniczych z 1993 r. (Trade Union Reform and Employment Rights Act) ${ }^{35}$ daje pracownicom w ciąży możliwość wykorzystania co najmniej 14 tygodni urlopu macierzyńskiego i uprawnia je do wzmocnionej ochrony ze strony zakładu pracy z przyczyn położniczych. Innym zapisem jest przyznanie pracownikom prawa do wyraźnego pisemnego określenia godzin pracy, wynagrodzenia i należnego urlopu, a także daje pracownikom ochrone przed zwolnieniem za korzystanie $\mathrm{z}$ ustawowych praw oraz ochronę przed represjami ze względu na podjęte prawne działania mające na celu

\footnotetext{
${ }^{29}$ Zob. więcej: http://www.legislation.gov.uk/ukpga/1982/46/contents.

${ }^{30}$ Umowa między związkiem zawodowym a pracodawcą, w której pojawia się zapis, że zakład pracy może zatrudnić albo członków związku albo tych, którzy do związku nie należą, lecz osoby zatrudnione, a niebędące członkami związku mają z góry określony czas na wstąpienie do związku, w przeciwnym wypadku stracą prace.

${ }^{31}$ Umowa między związkiem zawodowym a pracodawcą, w której pojawia się zapis, że zakład pracy zatrudni tylko tych, którzy już należą do związku, a taki pracownik ma obowiązek pozostać członkiem związku przez cały okres jego zatrudnienia.

${ }^{32}$ Zob. więcej: http://www.legislation.gov.uk/ukpga/1984/49.

${ }^{33}$ Zob. więcej: http://www.legislation.gov.uk/ukpga/1988/19.

${ }^{34}$ Zob. więcej: http://www.legislation.gov.uk/ukpga/1990/38.

${ }^{35}$ Zob. więcej: http://www.legislation.gov.uk/ukpga/1993/19/contents.
} 
ochronę zdrowia i bezpieczeństwo pracy. W ramach reformy regulacji dotyczących działalności związków zawodowych Ustawa z 1993 r. nie pozwalała na potrącanie składek członkowskich z wynagrodzenia pracownika bez jego pisemnej zgody, przyznała pracownikom prawo do decydowania, do którego związku chcą przystąpić ${ }^{36}$, określiła jako wymóg dla legalności strajku głosowanie wyłącznie drogą pocztową i zobligowała związek do poinformowania pracodawcy z co najmniej siedmiodniowym wyprzedzeniem o strajku.

Dzięki odrzuceniu przez Wielką Brytanię Europejskiej Karty Socjalnej, następnie

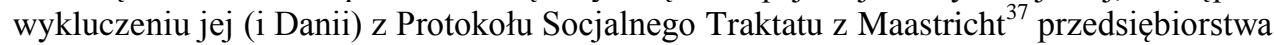
w Wielkiej Brytanii nie musiały od 1996 r. stosować się do dyrektywy o radach zakładowych. Rząd angielski argumentował, że nie mógł przyjąć dyrektywy z powodu jej prawdopodobnego wpływu na ograniczenie elastyczności rynku pracy poprzez narzucenie scentralizowanych i biurokratycznych form informacji i konsultacji. Niemniej jednak filie firm brytyjskich w innych krajach UE musiały postępować zgodnie z Dyrektywa w sprawie ustanowienia rad zakładowych (94/45/WE), o której mowa była już wcześniej. Jednakże w maju 1997 r. rządząca Partia Pracy przyjęła Protokół Polityki Społecznej Traktatu z Maastricht, który umożliwia państwom członkowskim UE na przegłosowanie niektórych przepisów prawnych rynku pracy kwalifikowaną większością głosów. Dodatkowe prawodawstwo UE w zakresie informacji i konsultacji z pracownikami (the European Information and Consultation Directive) ${ }^{38}$ pozwala pracownikom na uzyskiwanie informacji i na bieżące konsultacje na temat problemów w firmie, w których pracują (wniosek musi być złożony przez co najmniej 10\% pracowników w organizacji).

Poza przyjęciem Karty Socjalnej rząd Partii Pracy w latach 1997-2010 usankcjonował wiele przepisów prawnych, które zwiększyły stopień regulacji rynku pracy. Nowe przepisy weszły w życie w czerwcu 1998 r., kończąc system, według którego pracownicy musieli aprobować odliczenie składek od ich wynagrodzenia co trzy lata, co ustanowiono przepisami aktu z 1993 r. Ustawowa płaca minimalna obowiązuje od kwietnia 1999 r. Ustawę o stosunkach pracy (Employment Relations Act) uchwalono w lipcu 1999 r. ${ }^{39}$. Główne postanowienia obejmują wprowadzenie ustawowej procedury dla związków zawodowych w celu uzyskania akceptacji do negocjowania w imieniu wszystkich pracowników lub w wypadku przedsiębiorstw zatrudniających powyżej 20 osób w imieniu mniejszej grupy pracowników. Akt ten dał pracownikom prawo do obecności przedstawiciela związkowego podczas składania skarg lub wypełniania procedur dyscyplinarnych bez względu na to, czy ich firma uznaje związek. Dodatkowo Ustawa wzmocniła również niektóre indywidualne prawa pracowników - zwiększyła urlop macierzyński dla kobiet do 18 tygodni, dała pracownikom prawo do czasu wolnego w sytuacji nagłych wypadków.

Ustawa o zatrudnieniu (Employment Act) z 2002 r. $^{40}$ rozszerzyła prawa macierzyńskie - ustalono płatny urlop macierzyński (od 18 kwietnia 2003 r.) na 26 tygodni i uprawniono

\footnotetext{
${ }^{36}$ Jednak z zastrzeżeniem dotyczącym tych związków, które specjalizują się w handlu lub są związane z konkretnym zawodem - mogą one wykluczyć aplikantów, którzy się nie kwalifikują. ${ }^{37}$ Zob. więcej: http://www.cie.gov.pl/www/quest.nsf/0/975F03D3A5DC0D6DC1256E860027B120?Open.

${ }^{38}$ Zob. więcej: http://europe.ifj.org/assets/docs/224/020/66980e0-d7e6314.pdf.

${ }^{39}$ Zob. więcej: http://www.legislation.gov.uk/ukpga/1999/26/contents.

${ }^{40}$ Zob. więcej: http://www.legislation.gov.uk/ukpga/2002/22/contents.
} 
matki do korzystania z sześciomiesięcznego urlopu bezpłatnego, a ponadto przyznano ojcom prawo do dwóch tygodni płatnego urlopu ojcowskiego. Zobowiązano pracodawców do poważnego rozważenia wniosków od rodziców z małymi dziećmi (poniżej 6. roku życia) o elastyczne godziny pracy ${ }^{41}$.

W 2006 r. rząd ponownie zajął się prawami macierzyńskimi - Ustawa o pracy i rodzinach (Work and Families Act) ${ }^{42}$ rozszerzyła płatny urlop macierzyński do 39 tygodni, począwszy od kwietnia 2007 r., a dodatkowo stworzyła możliwość żądania przez rodziców/opiekunów nieletnich elastycznych godzin pracy. Akt pozwolił rządowi na wprowadzenie nowych zasad pozwalających ojcom na podjęcie dodatkowego urlopu ojcowskiego - nowe zasady pozwalają ojcom na skorzystanie $\mathrm{z}$ maksymalnie sześciomiesięcznego urlopu ojcowskiego, z czego trzy miesiące muszą dotyczyć drugiego półrocza życia dziecka, po powrocie matki do pracy.

Przyjęcie Karty Socjalnej pociągnęło za sobą konieczność przyjęcia kolejnych dyrektyw prawa pracy UE. Dyrektywa UE w sprawie urlopu wychowawczego ( $E U$ Directive on Parental Leave 1996/34/EC) weszła w życie w Wielkiej Brytanii 15 grudnia 1999 r., mając zastosowanie do dzieci, które nie ukończyły wówczas pięciu lat. Przyznała ona prawo rodzicom do trzynastotygodniowego urlopu bezpłatnego na opiekę dla każdego $\mathrm{z}$ ich dzieci w wieku do lat pięciu (warunkiem jest przynajmniej rok nieprzerwanej pracy rodzica i powiadomienie pracodawcy na co najmniej cztery tygodnie przed podjęciem takiego urlopu). Nowa dyrektywa (2010/18/UE), która rozszerza urlop wychowawczy do 18 tygodni, będzie obowiązywać w Wielkiej Brytanii od marca $2013 \mathrm{r}$.

Zebrane i znowelizowane przepisy dotyczace dyskryminacji stworzyły w 2010 r. jednolitą Ustawę o równości (The Equality Act) ${ }^{43}$. Dotyczy ona równego wynagradzania, równości ze względu na rasę, płeć i wiek, unikania dyskryminacji niepełnosprawnych $\mathrm{w}$ zakresie rekrutacji, promocji, szkoleń, zwolnień i emerytur.

Obecnie wiek emerytalny w Wielkiej Brytanii wynosi 65 lat dla mężczyzn. Dla kobiet wiek emerytalny wzrasta aż do wyrównania $\mathrm{z}$ mężczyznami: dla urodzonych przed 6 kwietnia $1950 \mathrm{r}$. wiek emerytalny to 60 lat, a dla tych urodzonych pomiędzy 6 kwietnia 1950 i 5 kwietnia 1953-60-65 lat, w zależności od daty urodzenia. Wiek emerytalny dla kobiet i mężczyzn wzrośnie w latach 2018-2020 do 66 lat. Dalszy wzrost, do 67 lat, przewidziany jest do wprowadzenia stopniowo w latach 2026-2028, a rozważany jest również wzrost wieku emerytalnego do 68. roku życia w latach 2044-2046 lub wcześniej. Rząd wycofywał zapis o wieku emerytalnym 65 lat jako wiek domyślny. W konsekwencji, od 1 października 2011 r., pracodawcy nie mają już prawa do zmuszenia pracowników do przejścia na emeryturę.

\section{ZGODNY KIERUNEK ZMIAN W PRAWIE PRACY FRANCJI I UNII EUROPEJSKIEJ}

Kompleksowy Kodeks pracy (Code du travail) we Francji wyznacza minimalne standardy dotyczące warunków pracy, w tym: czasu pracy, nadgodzin, wymiaru płatnego urlopu i czasu wolnego. Ustawa weszła w życie 1 maja 2008 r. (Ustawa 2008/67 z 21

\footnotetext{
${ }^{41}$ Prawo do żądania elastycznych godzin pracy rozszerzono na rodziców z dziećmi w wieku do lat 16 w kwietniu $2009 \mathrm{r}$.

${ }^{42}$ Zob. więcej: http://www.legislation.gov.uk/ukpga/2006/18/contents.

${ }^{43}$ Zob. więcej: http://www.legislation.gov.uk/ukpga/2010/15/contents.
} 
stycznia 2008 r. $)^{44}$. Mimo że przepisy nie zmieniły wcześniej istniejącego prawa, to stanowią one kompleksowy układ uproszczonego i do niedawna fragmentarycznego prawodawstwa $\mathrm{z}$ ostatnich 30 lat. Kodeks pracy reguluje stosunki umowne między pracodawcami i pracownikami oraz określa warunki zwalniania i przeprowadzenia niektórych procedur, a dodatkowo zawiera przepisy dotyczące reprezentacji pracowników i regulację składek pracowników do systemu ubezpieczeń społecznych. Pozostałe prawa i obowiązki są określone w umowach zbiorowych, negocjowane na szczeblu krajowym lub lokalnym pomiędzy związkami zawodowymi i stowarzyszeniami pracodawców. Kodeks pracy określa również podstawowe zasady układów zbiorowych.

Kodeks pracy zmieniono ustawą 391 z 4 maja 2004 r., osłabiając pozycję związków zawodowych na kilka sposobów: poprzez wymóg o reprezentowaniu większości siły roboczej, aby układ zbiorowy mógł być uznany; poprzez wprowadzenie większej elastyczności dla związków zakładowych zamiast związków sektorowych; poprzez umożliwienie reprezentowania pracowników przez małe grupy przedstawicieli niezwiązane z dużymi związkami. Prawdopodobnie pozycja związków została dodatkowo osłabiona przez Ustawę 2008/789 z 20 sierpnia 2008 r., choć jej przepisy ustalono wcześniej z organizacjami pracodawców i związków. Nowe prawo rozluźniło nieco kryteria ustalania reprezentacji pracowniczej w przedsiębiorstwie i usunęło domniemanie, że główne związki zawodowe reprezentatywne są na poziomie miejsca pracy. Przepisy weszły w pełni w życie w 2013 r. ${ }^{45}$.

Ustawa 2008/789 przewiduje także, że umowy dotyczące przedsiębiorstw są ważne tylko wtedy, gdy podpisały je związki lub organizacje pracownicze, które zdobyły co najmniej 30\% głosów oddanych w ostatnich wyborach w miejscu pracy. Jedynym wyjątkiem jest sytuacja, gdy organizacje $\mathrm{z}$ poparciem ponad 50\% głosów liczby zatrudnionych staną $\mathrm{w}$ opozycji. Podobne przepisy będą miały zastosowanie do umów sektorowych rozpoczynających się w $2013 \mathrm{r}$.

We Francji nielegalna jest dyskryminacja w zakresie wynagrodzenia i zatrudnienia ze względu na płeć, sytuację rodzinną, kwestie moralne, pochodzenie etniczne, religię, zdrowie lub niepełnosprawność. Firmy muszą omawiać programy równości seksualnej ze związkami w ramach umowy zbiorowej (Ustawa 2001/397 z 9 maja 2001 r.). Molestowanie seksualne i zastraszanie w miejscu pracy są nielegalne (Ustawa 2002/73 z 17 stycznia 2002 r.). Ochrona prawna przed dyskryminacją i molestowaniem, w tym ochrona przed odwetem dla tych, którzy zgłaszają lub zeznają w sprawie o dyskryminację, została wzmocniona wraz z naniesieniem poprawek w definicjach w Ustawie 2008/496 z 27 maja 2008 r. Było to formalne transponowanie do prawa francuskiego niektórych aspektów unijnej dyrektywy 2000/43/WE, 2000/78/WE i 2002/73/WE w sprawie równego traktowania bez względu na rasę lub pochodzenie etniczne, religię, płeć i z uwzględnieniem równości szans zatrudnienia, kształcenia i awansu zawodowego.

Podczas procesu rekrutacji potencjalni pracodawcy objęci są zakazem zadawania pytań, które nie są bezpośrednio związane z kwalifikacjami zawodowymi niezbędnymi do wykonania pracy w wystarczającym stopniu (Ustawa 1992/1446 z 31 grudnia 1992 r.). Pracodawcy muszą poinformować kandydatów o metodach stosowanych $\mathrm{w}$ trakcie postępowania rekrutacyjnego, a wyniki muszą pozostać poufne.

\footnotetext{
${ }^{44}$ Wszystkie omówione ustawy są dostępne w serwisie: http://legifrance.gouv.fr.

${ }^{45}$ The Economist Intelligence Unit, France Regulation - Human Resouces: Labour Law, Country Commerce France, May 2012.
} 
We Francji umowy o pracę są zazwyczaj sporządzane w formie pisemnej, ale nie ma ich prawnej definicji czy wzoru. Umowa musi zawierać stanowisko pracownika i pozycję w hierarchii korporacyjnej, musi przedstawić odszkodowania i świadczenia oraz czas obowiązywania (jeśli nie jest on nieograniczony). Otwarta forma umowy o pracę (CDI, contrat de durée inderminée) jest traktowana jako norma, a umowy na czas określony (CDDs, contrats de durée determine) podlegają określonym warunkom. Zatrudnienie przez CDD musi być sporządzone w formie pisemnej i zazwyczaj może być przedłużone nie więcej niż jeden raz. Pracownik zatrudniony na podstawie umowy na czas określony, ma również prawo do wypłaty premii w wysokości co najmniej $10 \%$ całości wynagrodzeń brutto wypłacanych na koniec umowy w ramach rekompensaty za brak bezpieczeństwa pracy (indemnité de précarité), choć może być wyższa lub niższa, jeśli tak stanowi porozumienie zbiorowe ${ }^{46}$. Jeżeli warunki te nie są spełnione przy zatrudnianiu pracownika, CDD automatycznie staje się umową na czas nieokreślony. Ponadto pracownik, którego język ojczysty jest językiem innym niż francuski, ma prawo domagać się thumaczenia umowy na jego język i ta wersja ma pierwszeństwo w wypadku sporu.

Kodeks pracy przewiduje różne rodzaje reprezentowania pracowników w zależności od wielkości firmy. Dla zatrudnionych w niepełnym wymiarze godzin i telepracowników stosuje się wskaźniki uwzględniające proporcje $\mathrm{w}$ porównaniu $\mathrm{z}$ poziomem zatrudnienia w pełnym wymiarze czasu. Wszystkie przedsiębiorstwa zatrudniające 11 i więcej osób muszą pozwolić na wybór delegatów pracowniczych, którzy wybierani są co cztery lata przez wszystkich zatrudnionych (liczba delegatów zależy od wielkości zatrudnienia). Delegaci powinni spotykać się $\mathrm{z}$ zarządem co najmniej raz w miesiącu. Są oni odpowiedzialni za przedstawienie indywidualnych lub zbiorowych skarg związanych $\mathrm{z}$ warunkami pracy, informowanie inspektorów rządowych o naruszeniach prawa pracy oraz za przyjmowanie i akceptację zmian w organizacji tygodnia pracy. Delegacje pracowników mają prawo do pełnopłatnego czasu wolnego i specjalnie wydzielonego miejsca w zakładzie pracy w celu wykonywania przydzielonych zadań.

Przedsiębiorstwa zatrudniające co najmniej 50 osób muszą mieć radę pracowniczą. Taka rada musi być konsultowana przez pracodawcę we wszystkich sprawach mających wpływ na firmę i musi być $\mathrm{z}$ wyprzedzeniem informowana o wszelkich decyzjach wpływających na warunki pracy. Rady nie mają prawa weta w stosunku do spraw korporacyjnych, ale mogą otrzymać finansowe i strategiczne informacje na temat działalności przedsiębiorstwa, mogą zadawać pytania oferentom przy próbach przejęcia przedsiębiorstwa i zwoływać posiedzenie wszystkich pracowników. Informacje muszą być przekazywane do rady $\mathrm{w}$ formie pisemnej co najmniej raz na kwartał $\mathrm{w}$ firmach $\mathrm{z}$ co najmniej 300 pracownikami i przynajmniej raz do roku, gdy zatrudnionych jest mniej niż 300 pracowników. Od 2009 r. (Dekret z 27 kwietnia 2009 r.) rady te powinny być konsultowane w sprawie wykorzystania funduszy przedsiębiorstwa. Próg wynosi 200000 euro dla subwencji i 1500000 euro dla kredytów i pożyczek refundowanych. Zasada ta ma zastosowanie niezależnie od tego, czy francuski rząd lub Unia Europejska jest źródłem funduszy.

Komitety pracownicze mogą dowolnie organizować w swoim przedsiębiorstwie imprezy społeczne i kulturalne, których koszty pokrywa firma. Aby sfinansować własne

\footnotetext{
${ }^{46}$ The Economist Intelligence Unit, France Regulation - Human Resouces: Labour Law, Country Commerce France, May 2012.
} 
koszty operacyjne, rada otrzymuje dotację $\mathrm{z}$ firmy $\mathrm{w}$ wysokości co najmniej $0,2 \%$ całkowitych rocznych płac.

Przedsiębiorstwa francuskie uiszczają opłaty na sfinansowanie szkoleń dla swoich pracowników i kursy dla osób bezrobotnych. Pracownicy muszą otrzymać czas wolny na okres szkolenia. Pracownicy mają prawo do 12 dni płatnego urlopu w celu odbycia szkolenia, a każdorazowo minimum dwa dni. Liczba pełnopłatnych dni wolnych na odbycie szkoleń wzrasta do 18 dni dla trenerów lub przedstawicieli związkowych. Kierownictwo przedsiębiorstwa może otrzymać do sześciu dni bezpłatnego urlopu szkoleniowego rocznie. Pracodawcy są zobligowani do udzielania pomocy finansowej dla pracowników, którzy zdobywają nowe kwalifikacje.

Podsumowując, należy podkreślić, że przepisy prawa pracy narzucone przez Unię Europejską nie zmieniły charakteru rynku pracy we Francji. Regulacje unijne albo zastąpiły już istniejące i obowiązujące prawo francuskie, albo bardzo nieznacznie zmieniły ich charakter, uzupełniając je. Ogólnie można stwierdzić, że prawodawstwo francuskie jest wysoce kompatybilne $\mathrm{z}$ legislacją UE i charakter obu zmierza w tym samym kierunku.

\section{PRÓBY UELASTYCZNIENIA WLOSKIEGO RYNKU PRACY OSTATNICH LAT}

Reformy prawa pracy objęte dekretem prawnym (LD, Legislative Decree ) 276/2003 wprowadziły nowe formy umów o pracę i tym samym większą elastyczność prawa pracy we Włoszech ${ }^{47}$. Ustawa przewiduje utworzenie internetowego Narodowego Pośrednictwa Pracy (Borsa del Lavoro), które ma działać regionalnie poprzez ItaliaLavoro (włoską agencję Ministerstwa Pracy i Ubezpieczeń Społecznych), a jej celem jest wymiana informacji na temat podaży i popytu na pracę, które mają być dostępne dla osób poszukujących pracy i pracodawców. Nowa usługa, Cliclavoro ${ }^{48}$, jest częścią innej inicjatywy ministerstwa, która ma na celu ułatwienie ogólnokrajowego poszukiwania pracy, umożliwiająca użytkownikom dostęp do ofert pracy poprzez Facebook, Twitter, LinkedIn i blogi osobiste.

Ustawy 296/2006 i 247/2007 wprowadziły zachęty mające na celu: zwiększenie mobilności i elastyczności zatrudnienia poprzez obniżenia dla pracodawcy składek na ubezpieczenie społeczne dla pracowników na umowy na czas nieokreślony o 3 punkty procentowe; przekazywanie środków na dofinansowanie nowych pracowników, tak długo, jak są oni zatrudnieni na co najmniej dwa lata; zapewnienia ze strony państwa, że będzie ono płacić składki emerytalne pracownikom w okresach bezrobocia. W porównaniu jednak z takimi krajami, jak Wielka Brytania i Stany Zjednoczone, rynek pracy we Włoszech nadal cechuje brak elastyczności.

Ustawa budżetowa z 2009 r. (Ustawa 203 z 23 grudnia 2008 r.) zniosła zakaz double dipping, czyli otrzymywania świadczeń emerytalnych w trakcie pracy, aby zachęcić ludzi do pozostania na rynku pracy w obliczu spadku aktywności gospodarczej.

W 2010 r. działania rządu koncentrowały się na stosowaniu środków w celu refinansowania świadczeń socjalnych dla grup o niskich dochodach dotkniętych przez światowy kryzys gospodarczy i na utrzymaniu wydajności pracy, oferując zachęty podatkowe za produktywność. Ustawa 220 z 13 grudnia 2010 r. przedłużyła na 12

\footnotetext{
${ }^{47}$ The Economist Intelligence Unit, Italy Regulation - Human Resouces: Labour Law, Country Commerce Italy, May 2012.

${ }^{48}$ www.cliclavoro.gov.it
} 
miesięcy plan dopłat do świadczeń społecznych, w tym finansowany przez państwo plan wypłat odszkodowań po utracie pracy (Cassa integrazione). Ponadto Krajowy Instytut Ubezpieczeń Społecznych (Istituto Nazionale della Previdenza Sociale) daje firmom zryczałtowaną zachętę w przypadku zatrudnienia pracowników, którzy są uprawnieni do otrzymania świadczeń socjalnych lub zasiłku dla bezrobotnych. Ustawa rozszerzyła również plan zachęt podatkowych na premie za wydajność (LD 185/2008). Pracownicy, których wynagrodzenia brutto były mniejsze niż 40000 euro rocznie, mogli się zdecydować na proporcjonalne opodatkowanie $10 \% \mathrm{w}$ ramach podatku od osób fizycznych (imposta sul redito delle persone fisiche) dodatkowego dochodu generowanego przez nadgodziny ${ }^{49}$.

Przepisy prawa pracy są ponownie reformowane jako część planu ratunkowego dla Włoch (Salva Italia, Ustawa 214 z 22 grudnia 2011 r.). ${ }^{50}$. Wiek emerytalny, który obecnie wynosi 60 lat dla kobiet i 65 dla mężczyzn, wzrasta do odpowiednio 62 i 66 (do końca 2012 r.). Wiek emerytalny dla kobiet nadal będzie rósł do 66 lat w roku 2018, a nie do 2026, jak wcześniej to planowano. Wszystkie emerytury i renty, z wyjątkiem najniższych, nie są indeksowane wskaźnikiem inflacji w 2012 i 2013 r., a w zwiększeniu elastyczności rynku pracy ma pomóc umożliwienie ludziom pracy do osiągnięcia wieku 70 lat.

Ponadto administracja premiera Monti wprowadziła kilka reform w prawie pracy, umieszczając stosowane zapisy w dekrecie Rozwój Włoch (Cresci Italia, Ustawa 24 z 24 stycznia 2012 r. $)^{51}$. Akt ten ma na celu zwiększenie konkurencyjności niektórych zawodów, przeprowadza reformę systemów licencjonowania, znosi minimalne opłaty za usługi lekarzy, prawników, notariuszy, farmaceutów i kierowców taksówek. Ma on również za zadanie osłabienie mocy artykułu 18 kodeksu pracy, który zakazuje zwalniania pracownika bez uzasadnionej przyczyny i zmusza pracodawców do ponownego zatrudnienia i wypłaty rekompensaty pracownikowi przy uznaniu zwolnienia za nieuzasadnione. Próby zreformowania tej klauzuli (wprowadzone jeszcze w 1970 r.) przez dekady nie doczekały się nawet dyskusji we włoskim parlamencie.

Ciekawapozostaje rozbieżność między regulacjami dla różnych dziedzin i dla różnych przedsiębiorstw. Na ogół to kodeks cywilny określa podstawowe prawa i obowiązki pracodawcy i pracownika. Prawo pracy dostarcza jednak najczęściej zupełnie różnych przepisów dla przemysłu $\mathrm{i}$ handlu (i dodatkowo odrębne przepisy dla rolnictwa, górnictwa, rzemiosła, turystyki itd.). Zasady różnią się również w zależności od wielkości przedsiębiorstwa. Prawo rozróżnia również robotników, pracowników umysłowych i menadżerów zarządzających. W praktyce zwolnienie pracowników umysłowych i menadżerów zarządzających jest prawie niemożliwe.

Relacje pracodawca-pracownik są zawsze oparte na umowie o pracę, która może być słowna $\mathrm{i}$ zwykle jest negocjowana indywidualnie $\mathrm{z}$ pracownikiem lub wspólnie ze związkami zawodowymi. Włoska konstytucja i Ustawa 300/1970 w sprawie praw pracowniczych i związkowych określa podstawowe prawa związkowe i prawo do przynależności do związku.

Prawo pracy zobowiązuje wszystkich pracodawców, wyłączając jedynie najmniejsze przedsiębiorstwa, do zatrudniania pewnej części „uprzywilejowanych” pracowników, to

\footnotetext{
${ }^{49}$ The Economist Intelligence Unit, Italy Regulation - Human Resouces: Labour Law, Country Commerce Italy, May 2012.

${ }^{50}$ Zob. więcej: http://www.governo.it/GovernoInforma/Dossier/salva_italia/.

${ }^{51}$ Zob. więcej: http://www.governo.it/GovernoInforma/Dossier/cresci_italia/.
} 
znaczy takich, którzy mają trudności z wejściem na rynek pracy bez pomocy. Przydziały tych pracowników w praktyce traktowane są pobłażliwie, a nacisk kładziony jest na tworzenie zachęt podatkowych poprzez przyznawanie okresowych zwolnień z płacenia składek zabezpieczenia społecznego przez pracodawców. Ustawa 223/1991 przewiduje, że $12 \%$ wszystkich nowo zatrudnionych pracowników mają stanowić ci „uprzywilejowani” wymagający pomocy.

Wszyscy pracodawcy we wszystkich sektorach, z wyjątkiem agencji zatrudnienia, mają obowiązek zgłoszenia nowych pracowników zatrudnionych na każdy rodzaj umowy do wojewódzkich centrów zatrudnienia na jeden dzień przed rozpoczęciem nowego kontraktu. Pracodawcy muszą zgłaszać również zmiany w umowach, takich jak przedłużenie umów krótkoterminowych lub zmiany z krótkoterminowych umów na te na czas nieokreślony.

Włoskie prawodawstwo dotyczące rynku pracy w obliczu światowego kryzysu finansowego rozpoczęło reformy ku uelastycznieniu rynku pracy. Jednakże długie dekady wysokiej ochrony pracownika nie ułatwiają reformatorom $\mathrm{w}$ realizacji tego zadania. Wydaje się jednak, że podjęte działania przynoszą skutki, co wyrażają rankingi indeksu ochrony zatrudnienia sporządzane corocznie przez OECD ${ }^{52}$.

\section{MODEL AMERYKAŃSKIEGO RYNKU PRACY VERSUS MODEL EUROPEJSKIEGO RYNKU PRACY}

Stany Zjednoczone należą do krajów o bardzo wysokich wskaźnikach elastyczności rynku pracy ${ }^{53}$. Uwagę zwraca przede wszystkim elastyczność wynagrodzeń i popytu na pracę, które ze względu na znikomą ochronę zatrudnienia dają szansę pracodawcom odpowiednio dostosowywać zatrudnienie lub wynagrodzenia w zależności od fazy cyklu koniunkturalnego. Pozwala to z kolei na zmniejszenie kosztów recesji, przynajmniej w kategoriach zatrudnienia. Kolejną zaletą tego rynku pracy jest wysoka mobilność siły roboczej, rozwinięte systemy kształcenia zawodowego skierowane na szybkie przekwalifikowanie i szkolenie pracowników w zależności od potrzeb.

Ostatnie badania elastyczności liczby tworzonych miejsc pracy względem płac w gospodarce Stanów Zjednoczonych ujawniły, że wskaźniki te się pogorszyły ${ }^{54}$. Relatywnie niską elastyczność liczby nowych miejsc pracy względem płac autorzy badań tłumaczą tym, że społeczeństwo amerykańskie wykazuje coraz mniejszą skłonność do tworzenia nowych miejsc pracy i przejawiania przedsiębiorczości w sytuacji, gdy koszty pracy się obniżają, a zmienne zyski są coraz wyższe. Oczywiście okresowe pogorszenie się wskaźników może wynikać z prób stabilizacji cen, które wpływały negatywnie na skuteczne dostosowania płac realnych.

\footnotetext{
${ }^{52}$ Więcej na ten temat w kolejnym punkcie opracowania.

${ }^{53}$ Por. badania: OECD, Employment Outlook 2010, http://www.oecd.org/statsportal/; O. Blanchard, P. Portugal, What Hides behind an Unemployment Rate: Comparing Portuguese and US Labor Market, „American Economic Review” 91/1 (2001), s. 187-207; J. Botero , S. Djankov, R.L. Porta, F.L. Silanes, Shleifer, The Regulation of Labor, „Quarterly Journal of Economics” 1194 (2004), s. 1339-1382.

${ }^{54}$ P. Beaudry, D.A. Green, B.M. Sand, How Much Is Employment Increased by Cutting Labor Costs? Estimating the Elasticity of Job Creation, NBER Working Paper, No. 15790, February 2010, s. 24-26.
} 
Taką charakterystykę rynku pracy odzwierciedlają stosunkowo niskie poziomy stopy bezrobocia. Elastyczność rynku przekłada się na lepsze wykorzystywanie dostępnego czynnika, co wiąże się z wynikami całej gospodarki. Średnioroczny poziom bezrobocia dla Stanów Zjednoczonych na tle innych krajów zaprezentowano na rysunku 1 . Wynika z niego, że bezrobocie w Stanach Zjednoczonych przeważnie osiąga niższy poziom niż krajach Unii Europejskiej. Stosunkowo wysoki poziom bezrobocia (w ostatnich dwóch dekadach) odnotowywały Włochy. Duża elastyczność brytyjskiego rynku pracy, jak na standardy europejskie, pozwala tej gospodarce na osiąganie zbliżonych wyników do tych, które rejestruje gospodarka amerykańska.

Rys. 1. Stopa bezrobocia w wybranych krajach w latach 1990-2010 (w procentach)

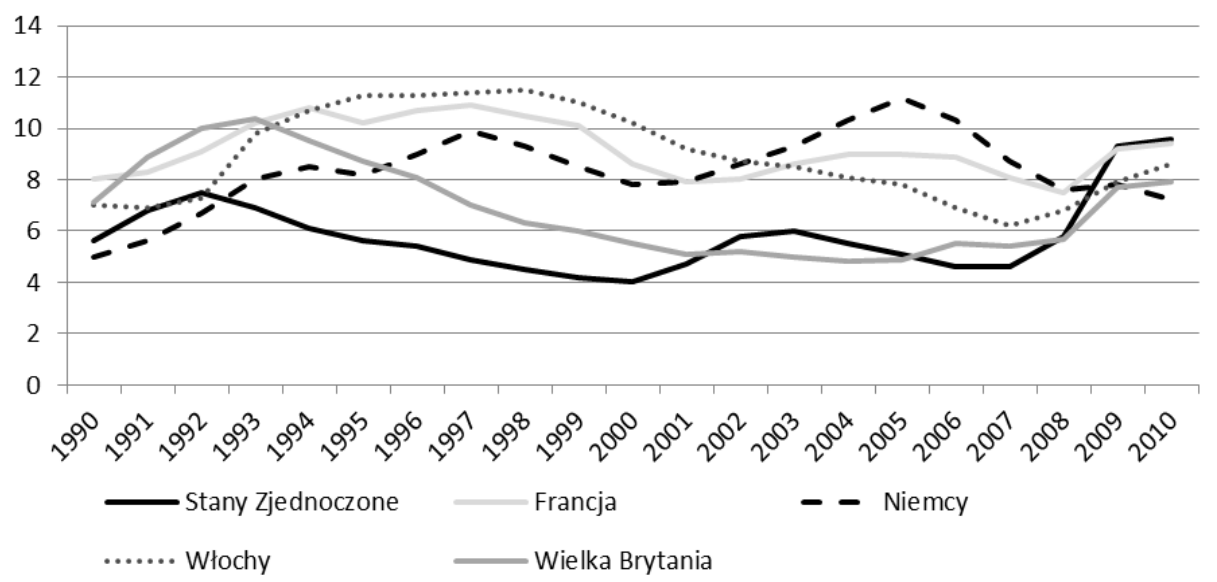

Źródło: opracowanie własne na podstawie: U.S. Census Bureau, The 2012 Statistical Abstract of the United Stated of America, Tab. 1365, http://www.census.gov/compendia/statab/.

Indeks ochrony zatrudnienia skonstruowany przez OECD służy ocenie procedur oraz kosztów wynikających ze zwolnień indywidualnych pracowników lub zwolnień grupowych, a także ocenie procedur uruchamianych w celu zatrudnienia pracownika na czas określony lub nieokreślony. Należy wspomnieć, że ochrona zatrudnienia odnosi się wyłącznie do jednego wymiaru zestawu czynników oddziałujących na elastyczność rynku pracy. Indeksy te są budowane na bazie oceny 21 cech rynku pracy obejmujących trzy zasadnicze aspekty ochrony zatrudnienia:

- indywidualne zwolnienia pracowników;

- koszty zwolnień zbiorowych;

- regulacje kontraktów na czas określony.

Każda $\mathrm{z}$ tych grup pozwala na ocenę rynku pracy za pomocą skali $0-6$, przy czym 0 oznacza najniższy stopień restrykcyjności regulacji ochrony zatrudnienia, 6 zaś informuje o ich najwyższym stopniu surowości. Powstałe indeksy za pomocą średniej ważonej wyrażają ogólny stopień ochrony zatrudnienia. W 2008 r. ocena dla Stanów Zjednoczonych wyniosła 0,21, dla Wielkiej Brytanii - 0,45, dla Włoch $-1,89$, dla Niemiec - 2,12, dla Francji - 3,05. 
Biorąc pod uwagę zmienność indeksu w czasie, na rysnku 2 przedstawiono jego wartości dla wszystkich analizowanych gospodarek w latach 1990-2008.

Spośród wybranych krajów rozwiniętych rynek pracy w Stanach Zjednoczonych charakteryzuje się najniższym wskaźnikiem ochrony zatrudnienia, co ma znaczenie dla jego elastyczności. Wyjątkowe wyniki osiąga również ta gospodarka pod względem poziomu aktywności zawodowej Amerykanów - w ostatnich dwóch dekadach wskaźnik ten wynosił średnio $62-64 \%$ populacji w wieku produkcyjnym ${ }^{55}$, podczas gdy dla Wielkiej Brytanii - 56-58\%, Niemiec i Francji - 51-52\%, a dla Włoch $-43-44 \%$.

Rys. 2. Indeks ochrony zatrudnienia w wybranych krajach w latach 1990-2008

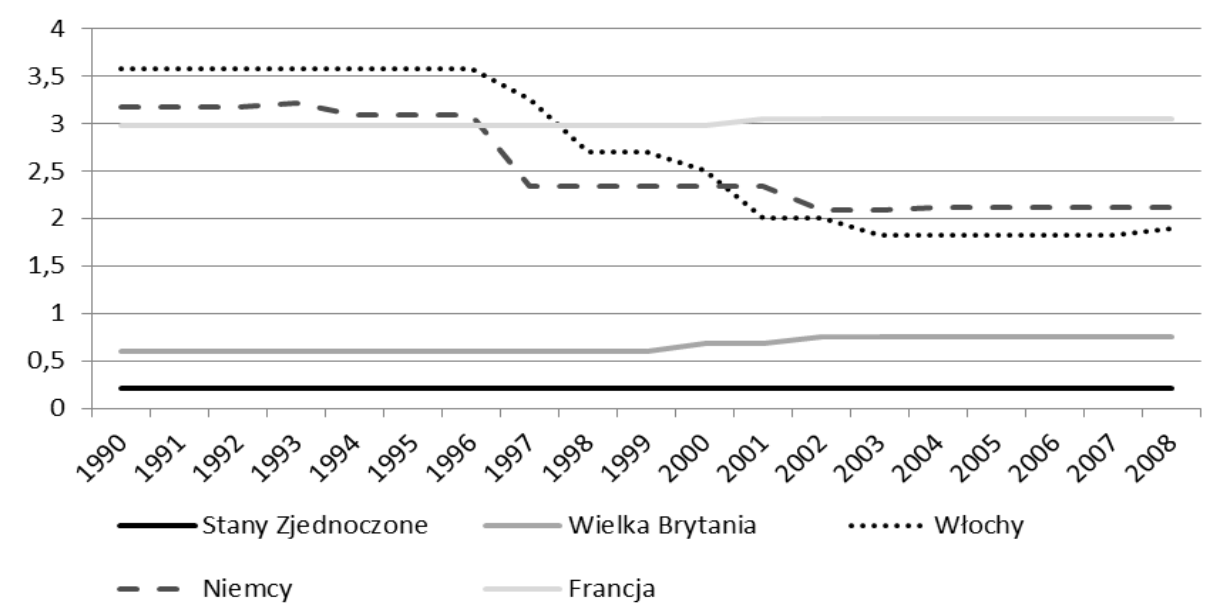

Źródło: opracowanie własne na podstawie: OECD, Employment Outlook 2012, http://stats.oecd.org/.

Rynek pracy w Stanach Zjednoczonych charakteryzuje się niskim poziomem ochrony zatrudnienia. Wynika to głównie z niskiego stopnia uzwiązkowienia oraz ze względów historycznych - amerykański rynek pracy można określić mianem rynku pracodawcy. Pozwala to jednak na jego uelastycznienie ze względu na swobodę przechodzenia do prac dorywczych (tymczasowych), swobodę zatrudnień i zwolnień oraz wysoką mobilność popytu na pracę. Wskaźnik uzwiązkowienia w Stanach Zjednoczonych w 2011 r. wyniósł $11,3 \%$ wśród wszystkich zatrudnionych, we Francji był on jeszcze niższy i wyniósł w 2009 r. 7,7\%, w Niemczech osiągnął poziom 18,5\% w 2010 r., w Wielkiej Brytanii 25,8\% w 2011 r., a we Włoszech 35,1\% w 2010 r. $^{57}$.

Historycznie w gospodarce amerykańskiej przyjęto doktrynę at-will employment, co oznacza, że pracodawca ma decydujący wpływ na sytuację pracownika i nie jest on zbyt mocno ograniczany w tej kwestii. Tylko istnienie w zakładzie pracy umowy pracodawcy ze związkami może wpłynąć na ograniczenie doktryny at-will employment. Wywodzi się

\footnotetext{
${ }^{55}$ U.S. Departament of Labor 2010

${ }^{56}$ Dane zaczerpnięte z: U.S. Census Bureau, The 2012 Statistical Abstract of the United Stated of America, Tab. 1365, http://www.census.gov/compendia/statab/.

${ }^{57}$ Przedstawione dane to najbardziej bieżące statystyki zaczerpnięte z: OECD, Employment Outlook 2012, http://stats.oecd.org/.
} 
ona z prawa zwyczajowego Wielkiej Brytanii, obowiązuje do dziś, z pewnymi ograniczeniami wprowadzonymi w latach trzydziestych i sześćdziesiątych XX wieku. Jedną z jej specyficznych instytucji jest brak pisemnej umowy o pracę - większość umów o pracę w Stanach Zjednoczonych zawierana jest w formie ustnej rozmowy pracownika $\mathrm{z}$ pracodawcą. W większości krajów europejskich obowiązuje zasada pisemnej umowy o pracę (wyjątkiem są Włochy), przyjętej zwyczajowo lub wymuszonej przez przepisy prawne, co w Stanach Zjednoczonych praktykowane jest niemal wyłącznie przy zatrudnianiu specjalistów oraz kadry wysokiego szczebla pracowniczego.

$\mathrm{Na}$ tle międzynarodowych rynków pracy Stany Zjednoczone nie należą do państw bezpieczeństwa społecznego. W przeciwieństwie do systemów społecznych charakterystycznych dla krajów europejskich, amerykańskie systemy mają nie tylko znacznie krótszą historię, ale też nie są tak uniwersalne, gdyż dotyczą niewielkiego odsetka najuboższych rodzin.

Okres wypowiedzenia umowy o pracę w Stanach Zjednoczonych nie został zdefiniowany przez Ustawę o uczciwych warunkach pracy (The U.S. Fair Labor Standards Act), regulacje dotyczą jedynie zwolnień zbiorowych (sześćdziesięciodniowy okres wypowiedzenia). Należy zauważyć, że takie rozwiązanie jest niedopuszczalne w ujęciu prawa europejskiego.

$\mathrm{Na}$ pewno wspólnym kierunkiem zmian we wszystkich omawianych krajach, łącznie ze Stanami Zjednoczonymi, jest zaostrzenie przepisów dotyczących dyskryminacji i równości szans w zatrudnianiu. Dużymi rozbieżnościami cechuje się natomiast prawo związkowe, niezwykle rozbudowane w Europie, w Stanach Zjednoczonych o bardzo ograniczonym zakresie.

$\mathrm{W}$ stosunku do amerykańskich regulacji związanych $\mathrm{z}$ działaniami zbiorowymi najbliższe prawodawstwo występowało w Wielkiej Brytanii, choć wdrożenie niektórych przepisów unijnychnie pozwala na ocenę brytyjskiego rynku pracy jako równie elastycznego co amerykański. Drugą skrajnością w ramach analizowanych przepisów prawa pracy wydają się Włochy, gdzie zwolnienie pracownika specjalisty do niedawna wydawało się prawie niemożliwe. Nie potwierdza tego jednak wskaźnik ochrony zatrudnienia skonstruowany przez OECD, wskazując raczej na Francję jako tę gospodarkę, która legislacyjnie usztywnia swój rynek pracy.

\section{ZAKOŃCZENIE}

Na podstawie przeprowadzonej analizy podstawowych aktów prawnych rynku pracy obowiązujących w Stanach Zjednoczonych oraz w wybranych czterech krajach Unii Europejskiej można pozytywnie zweryfikować hipotezę badawczą o mniejszej restrykcyjności regulacji rynku pracy w Stanach Zjednoczonych niż w krajach Unii Europejskiej. Uzasadnione może być również stwierdzenie, że wpływa to na uelastycznienie amerykańskiego rynku pracy, jego szybsze dostosowania, co ilustruje stopa bezrobocia rejestrowana w każdym z analizowanych krajów. Należy jednak być ostrożnym w takiej ocenie, gdyż zwykle niższa stopa bezrobocia w Stanach Zjednoczonych niż w krajach europejskich nie jest regułą w całym okresie badawczym ze względu na występujące na świecie szoki asymetryczne, a elastyczność rynku pracy wynika również z innych cech gospodarki, takich jak mobilność siły roboczej czy wycena czasu wolnego. 


\section{LITERATURA}

[1] Beaudry P., Green D.A., Sand, B.M., How Much Is Employment Increased by Cutting Labor Costs? Estimating the Elasticity of Job Creation, NBER Working Paper, No. 15790, February 2010.

[2] Blanchard O., Portugal P., What Hides behind an Unemployment Rate: Comparing Portuguese and US Labor Market, „American Economic Review” 91/1 (2001), s. 187-207;

[3] Botero J., Djankov S., Porta R.L., Silanes F.L. i Shleifer A., The Regulation of Labor, „Quarterly Journal of Economics” 119/4 (2004), s. 1339-1382.

[4] OECD, Employment Outlook 2010, http://www.oecd.org/ (dostęp: 19 września 2010).

[5] OECD, Employment Outlook 2012, http://stats.oecd.org/ (dostęp: 14 grudnia 2012).

[6] OECD, Pensions at a Glance 2005, http://www.oecd.org/els/socialpoliciesanddata/pensionsataglance2005.htm (dostęp:14 grudnia 2012)

[7] Kozłowski S.G., Wpółczesna Ameryka. Mity i rzczywistość,Wydawnictwo Uniwersytetu Marii Curie-Skłodowskiej, Lublin 2001.

[8] Serwis internetowy amerykańskiego ministerstwa pracy: http://www.dol.gov/.

[9] Serwis internetowy prawa francuskiego: http://legifrance.gouv.fr.

[10]Serwis internetowy prawa niemieckiego: http://dejure.org/.

[11] Serwis internetowy rządu włoskiego: http://www.governo.it/GovernoInforma/.

[12] Serwis prawny rządu brytyjskiego: http://www.legislation.gov.uk/ukpga/.

[13]The Economist Intelligence Unit, France Regulation - Human Resouces: Labour Law, Country Commerce France, May 2012.

[14]The Economist Intelligence Unit, Germany Regulation - Human Resouces: Labour Law, Country Commerce Germany, May 2012.

[15]The Economist Intelligence Unit, Germany Regulation - Human Resouces: Labour Law, Country Commerce Germany, September 1996.

[16]The Economist Intelligence Unit, Italy Regulation - Human Resouces: Labour Law, Country Commerce Italy, May 2012

[17]The Economist Intelligence Unit, US Regulation - Human Resouces: Labour Law, Country Commerce United States, September 1996.

[18]U.S. Census Bureau, The 2012 Statistical Abstract of the United Stated of America, http://www.census.gov/compendia/statab/ (dostęp: 16 grudnia 2012).

[19]U.S. Census Bureau, Government Employment \& Payrol, http://www.census.gov/govs/apes/ (dostęp: 20 września 2010).

[20]U.S. Department of Labor 2010, Labor Force Statistics from the Current Population Survey. http://www.bls.gov/ (dostęp: 1 października 2010).

\section{EVOLUTION OF SOME OF THE LABOUR MARKET REGULATIONS - COMPARATIVE ANALYSIS OF AMERICAN SOLUTIONS AGAINST EUROPEAN SOLUTIONS}

The paper discusses trends in the legislative process of defining relations in the economy. With regard to labor market institutions attention has been focused primarily on 
the level of employment protection and the role of trade unions. The analysis was conducted in relation to the following countries: the United States of America and representatives of the European Union: Germany, Great Britain, France and Italy.

The hypothesis of the research is the assertion that labor market regulations in the United States are less restrictive than is the case in some European Union countries, which affects the flexibility of the labor market and its rapid adaptation (as measured by the unemployment rate). For the verification of that hypothesis was used method as the analysis of basic changes in the regulation of the labor market the elected representatives of the European Union and the United States. The purpose of this article is therefore to trace the direction of changes in the legislative process of labor law and confront them with each other in order to verify the research hypothesis.

The work consists of five parts. The first one refers to the liberal nature of labor market regulation in the United States - analysis constitutes the background for comparison with European countries. The second part deals with the development of the negotiations and the principle of co-decision as the main characteristics of labor relations in Germany. In the next section attention has been focused on legislative stiffening the labor market in the past two decades in the UK. The fourth section discusses the common direction of the evolution of labor law in the European Union and France. Then, in the next section, reference is made to contemporary attempts to loosen the Italian labor market legislative changes. The work ends with an attempt to confront the American model of the European model.

Keywords: labor market, labor law, United States, Europe.

DOI:10.7862/rz.2013.hss.46

Tekst złożono w redakcji: wrzesień 2013.

Przyjęto do druku: marzec 2014. 